\title{
Phytochemical Screening, GC-MS Analysis and Biological Activities of Extracts of Artemisia vulgaris Linn.
}

\author{
Rashma Chaudhary ${ }^{1}$, Binita Maharjan ${ }^{1}$,Samjhana Bharati ${ }^{1}$, Timila Shrestha ${ }^{1}$, Pawan Kumar Mishra ${ }^{2}$,Sangita Karanjit ${ }^{3}$, \\ Deval Prasad Bhattarai', Puspa Lal Homagai, Ram Lal (Swagat) Shrestha, ${ }^{1,4 *}$ \\ ${ }^{1}$ Department of Chemistry, Amrit Campus, Institute of Science and Technology, Tribhuvan University, Lainchaur, Kathmandu, \\ Nepal \\ ${ }^{2}$ Department of Chemistry, Tri-Chandra Multiple Campus, Institute of Science and Technology, Tribhuvan University, Ghan- \\ taghar, Kathmandu, Nepal \\ ${ }^{3}$ Institute of Biomedical Sciences, Graduate School of Pharmaceutical Sciences, Tokushima University Shomachi 1-78, \\ Tokushima, 770-8505 Japan \\ ${ }^{4}$ Institute of Natural Resources Innovation, Kalimati, Kathmandu, Nepal \\ *E-mail: swagatstha@gmail.com
}

(Received:21 April 2021, Received in revised form: 18 April, Accepted: 21 June 2021, Available Online)

\section{Highlights}

- Aerial part of Artemisia vulgaris was extracted in methanol, hexane and chloroform.

- $\quad$ GC-MS analysis showed the presence of 12 different compounds.

- Antibacterial activity showed potent results.

- $\quad \mathrm{IC}_{50}$ value was calculated as $1.50 \mathrm{mg} / \mathrm{mL}$ and $\mathrm{LC}_{50}$ value as $0.18 \mathrm{mg} / \mathrm{mL}$.

- $\quad$ TPC (87.75 mg gallic acid equivalent/g) and TFC (47.25 mg quercetin equivalent/g).

\begin{abstract}
The aerial parts of Artemisia vulgaris were subjected for successive extraction in solvents methanol, hexane and chloroform, respectively, and compounds present in extract were analysed by GC-MS analysis 12 different compounds were found in chloroform extract in which Germacrene was found most abundantly (33.84\%). Chloroform extract showed strong antibacterial activity, which was examined against 6 bacteria using the disc diffusion method. The $I_{50}$ value of chloroform extract accounted for $1.50 \mathrm{mg} / \mathrm{mL}$. The TPC content of the extract was found to be $87.75 \mathrm{mg}$ gallic acid equivalent/g of dry extract, whereas TFC content was found to be $47.25 \mathrm{mg}$ quercetin equivalent/g of dry extract and exhibited $\mathrm{LC}_{50}$ value of $0.18 \mathrm{mg} / \mathrm{mL}$.
\end{abstract}

Keywords: Artemisia vulgaris, Phytochemical screening, GC-MS, Biological Activity

\section{Introduction}

Artemisia vulgaris Linn. is an important perennial medicinal herb that belongs to the family Asteraceae, commonly called Mugwort pollen in Hindi and Titepati in Nepali. The perennial plant A. vulgaris grows to a height of 50-150 cm, flowers in August, and sets seeds in September. A. vulgaris has long been used as a traditional remedy in public health, as well as an edible plant (primarily as a spice) [1]. It is an aggressive and invasive plant that is found growing wild and abundantly all over the temperate and cold temperate zones of the world. It is somewhat toxic, and several pharmacological activities of $A$. vulgaris have been reported $[2,3]$.

${ }^{*}$ Corresponding author 
All parts of the plant are found to be anthelmintic, antiseptic, antispasmodic, carminative, cholagogue, diaphoretic, digestive, emmenagogue, expectorant, nervine, purgative, stimulant, slightly tonic, and they are also used to cure women's complaints. The leaves are used as an appetizer, diuretic, hemostatic and stomachic. The leaves of the plant have an antibacterial action, inhibiting the growth of Staphylococcus aureus, Bacillus typhi, Shigella dysenteriae, Streptococci, Escherichia coli, Bacillus subtilis, Pseudomonas. The stem is also antispasmodic, antirheumatic, and stomachic [4,5].

Leaves of A. vulgaris were successively extracted in three different solvents, methanol, hexane and chloroform, respectively then different biological tests were carried out to check the potency of extract as an antioxidant, antibacterial and its cytotoxicity, which could be very beneficial to discover new synthetic drugs with less toxicity and side effects.

\section{Materials and Methods}

\section{Collection of plant materials}

The fresh leaves of A. vulgaris were collected from Chovar, Kathmandu, Nepal, in the month of October 2018. The collected leaves were washed, shade dried and grinded to make powder.

\section{Extraction}

The dried powdered leaves of $A$. vulgaris were extracted successively in three different solvents methanol, hexane and chloroform, respectively. Firstly, it was dissolved in methanol for about 15 days and was filtered then concentrated using a Rota evaporator. Then concentrated methanol extract was suspended with $1 \% \mathrm{HCl}$; then, it was neutralized using $\mathrm{NH}_{4} \mathrm{OH}$. Thus, the prepared solution was subjected for extraction with hexane from which aqueous layers were taken for further extraction with chloroform. After mixing with chloroform, the solution was shaken vigorously in a separating funnel to separate chloroform extract from the aqueous layer. Thus, obtained chloroform extract was concentrated using a Rota evaporator.

\section{Phytochemical Screening}

To find the main class of chemical compounds present in the plant extracts, phytochemical screening was carried out on methanol, hexane and chloroform extracts as per the standard methods [6-8].

\section{Antibacterial Activity}

To check the capacity of plant extracts to kill or inhibit the growth of pathogenic micro-organisms, antibacterial activity was carried out. The antibacterial screening of plant extracts was carried out by the agar well diffusion method based on the procedure given by chemists $[9,10]$. All the strains of bacteria were grown in nutrient agar at $37^{\circ} \mathrm{C}$ and reactivated for further use in nutrient broth. The different extracts of $A$. vulgaris and standard drugs were tested for antimicrobial activity against the test organisms using the agar diffusion method [11].

Mueller Hinton agar media was prepared, and the plates were swabbed for 24 hours with cultures of the bacteria that had been cultured overnight in nutrient broth. $0.5 \mathrm{~mL}$ of each extract and Dimethyl sulphoxide (DMSO) were individually impregnated into $8 \mathrm{~mm}$ diameter sterile discs. DMSO was used as negative control and discs of standard drugs as a positive control. The plates were then incubated at $37{ }^{\circ} \mathrm{C}$ for 24 hours. After the incubation period, each plate was observed for the zone of inhibition and measured using a transparent scale or slide callipers [12].

\section{Antioxidant Activity}

Antioxidant activity of plant extract was carried out to check the ability of the extract to kill or scavenge the free radicals, which are responsible for the oxidation reaction. It was examined by using DPPH free radical scavenging method. In this method, first of all, a stock solution of concentration $1 \mathrm{mg} / \mathrm{mL}$ was prepared by dissolving $1 \mathrm{mg}$ of sample in $1 \mathrm{~mL}$ of methanol, then $0.1 \mathrm{~mL}$ of these solutions were added to $0.1 \mathrm{~mL}$ of $0.1 \mathrm{mM} \mathrm{DPPH}$ (prepared in methanol) and was left for 30 minutes in a dark room. After 30 minutes, their absorbance was taken at $517 \mathrm{~nm}$ against DPPH, DMSO was used for a blank test and as standard, Quercetin was prepared. The sample with yellow colour (more than 50\% inhibition than control) was taken for further testing, which was anticipated to be potent antioxidants [13].

To examine the $\mathrm{IC}_{50}$ value against DPPH, extracts with different concentrations were prepared by a two-fold dilution method [14]. 
The percentage of radical scavenging activity was calculated by using the following formula:

Where,

$$
\text { Percentage scavenging }=\frac{\left(A_{o}-A_{T}\right)}{A_{o}} \times 100 \%
$$

$\mathrm{A}_{0}=$ Absorbance of the DPPH

$\mathrm{A}_{\mathrm{T}}=$ Absorbance of the DPPH free radical solution containing the sample extract.

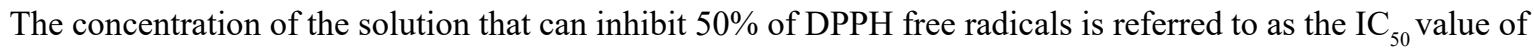
the extract, which has an inverse relation with antioxidant activity [15].

\section{Total Phenolic Content}

The content of total phenolic compounds in chloroform extracts was determined by Folin-Ciocalteu method. For the preparation of calibration curve $1 \mathrm{~mL}$ aliquots of $0.024,0.075,0.105$ and $0.3 \mathrm{mg} / \mathrm{mL}$ ethanolic gallic acid solutions were mixed with $5 \mathrm{~mL}$ Folin-Ciocalteau reagent (diluted ten-fold) and $4 \mathrm{~mL}(75 \mathrm{~g} / \mathrm{L})$ sodium carbonate. The absorption was read after 30 minutes at $20{ }^{\circ} \mathrm{C}$ at $765 \mathrm{~nm}$, and the calibration curve was drawn. $1 \mathrm{~mL}$ chloroform extract $(10 \mathrm{~g} / \mathrm{L})$ was mixed with the same reagents as explained above, and after 1 hour, the absorption was measured for the determination of plant phenolics. All determinations were performed in triplicate [16]. The total content of phenolic compounds in plant methanol extracts in gallic acid equivalents (GAE) was calculated by the following formula:

$$
\begin{aligned}
& \qquad \mathrm{TPC}=\frac{C \times V}{m} \\
& \text { Where, } \\
& \mathrm{C}=\text { the concentration of gallic acid founded from the calibration curve, } \mathrm{mg} / \mathrm{mL} \text {; } \\
& \mathrm{V}=\text { the volume of extract, } \mathrm{mL} \text {; } \\
& \mathrm{m}=\text { the weight of pure plant chloroform extract, } \mathrm{g}
\end{aligned}
$$

\section{Total Flavonoid Content}

$1 \mathrm{~mL}$ of sample $\left(0.1 \mathrm{mg} / \mathrm{mL}\right.$ in methanol) was mixed with $1 \mathrm{~mL}$ of $2 \% \mathrm{AlCl}_{3}$ (dissolved in methanol) and kept for 1 hour, and absorbance was measured at $415 \mathrm{~nm}$ against the blank (methanol). Quercetin was used as standard. Total flavonoid content is stated as $\mathrm{mg}$ of quercetin equivalents per gram of dried sample [17].

The concentration of total flavonoid content in the sample was determined as milligram of quercetin equivalent by using the following equation:

$$
\mathrm{TFC}=\frac{C \times V}{m}
$$

Where,

$\mathrm{C}=$ concentration of quercetin from curve $(\mu \mathrm{g} / \mathrm{mL})$

$\mathrm{V}=$ volume of extract $(\mathrm{mL})$

$\mathrm{m}=$ weight of plant extract $(\mathrm{g})$

\section{Brine Shrimp Lethality Assay}

Brine shrimp (Artemia salina, fairy shrimp, or sea monkeys) lethality assay is commonly used to check the cytotoxic effect of bioactive chemicals. It is a rapid (24 hours), inexpensive and straightforward test as no aseptic techniques are required. The nauplii of brine shrimp were exposed to different concentrations of solutions of chloroform extracts of $A$. vulgaris for 24 hours. The number of motile nauplii was calculated that represented the effectiveness of the chloroform extracts.

Extracts having $\mathrm{LC}_{50}$ value less than $1 \mathrm{mg} / \mathrm{mL}$ are considered as bioactive in toxicity evaluation by Brine shrimp lethality assay $[18,19]$. 


\section{Results and Discussion}

\section{Phytochemical Screening}

Phytochemical screening was performed in all three extracts, methanol, hexane and chloroform extracts of $A$. vulgaris. More polar extracts showed the presence of a large number of compounds, whereas very few compounds were found in the less polar extract.

Table 1: Phytochemical screening of plant extracts

\begin{tabular}{|l|c|c|c|l|}
\hline Constituents & Methanol & Hexane & Chloroform & Presence \\
\hline Alkaloids & + & + & + & Alkaloids were present in all three extracts \\
\hline Flavonoids & + & + & + & Flavonoids were present in all three extracts \\
\hline Glycosides & + & + & + & Glycosides were present in all extracts \\
\hline Phenols & + & - & + & $\begin{array}{l}\text { Phenols were present in methanol and } \\
\text { chloroform extracts }\end{array}$ \\
\hline Quinones & - & - & - & Quinones were absent in all extracts \\
\hline Tannins & + & - & + & $\begin{array}{l}\text { Tannins were present in methanol and } \\
\text { chloroform extracts }\end{array}$ \\
\hline Saponins & + & - & $\begin{array}{l}\text { Saponins were present in methanol and } \\
\text { chloroform extracts }\end{array}$ \\
\hline Carbohydrates & + & - & + & $\begin{array}{l}\text { Carbohydrates were present in methanol } \\
\text { and chloroform extracts }\end{array}$ \\
\hline Protein & + & + & + & \begin{tabular}{l} 
Protein was present in all extracts \\
\hline Emolin
\end{tabular} \\
\hline
\end{tabular}

'+'indicates the presence and '- ' the absence.

\section{GC-MS spectra analysis of chloroform extract}

GC-MS chromatogram of chloroform extract showed the presence of 12 major compounds, which are presented below:

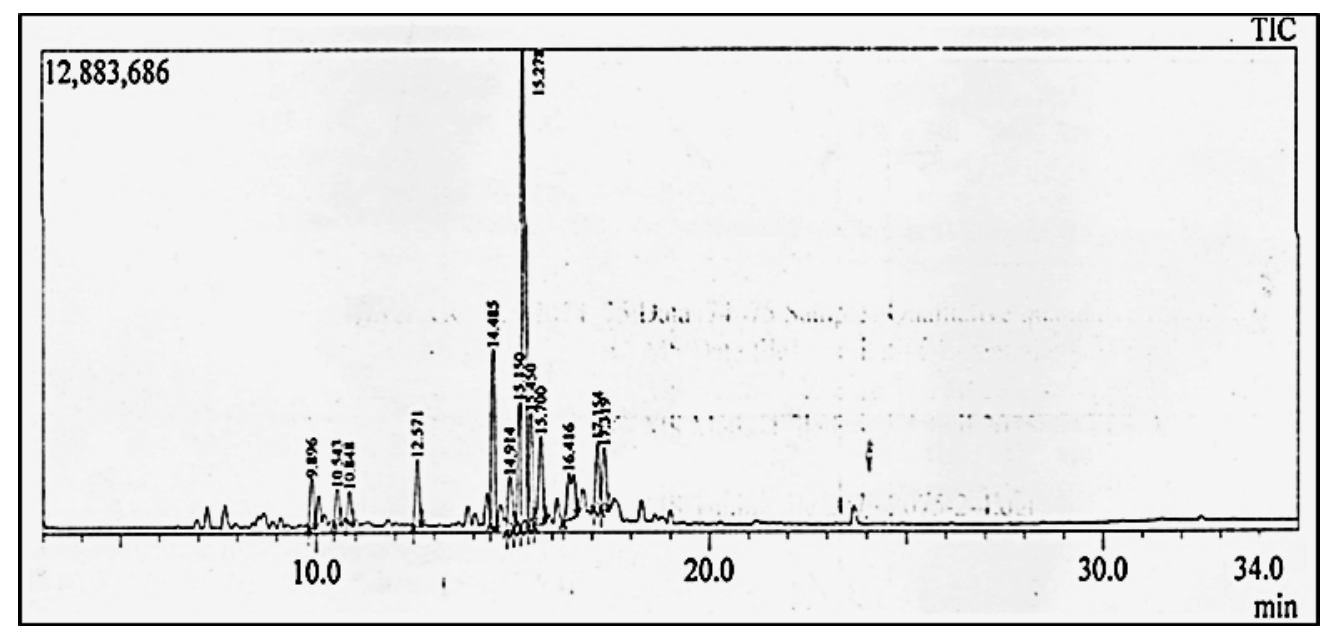

Fig1: Chromatogram of chloroform extract of A. vulgaris 
Table 2: Compounds present in the chloroform extract

\begin{tabular}{|c|l|c|c|c|c|}
\hline S.N. & Name of the compound & Retention time & Molecular formula & Molecular weight & Area (\%) \\
\hline 1 & Germacrene & 15.275 & $\mathrm{C}_{15} \mathrm{H}_{24}$ & 204 & 33.84 \\
\hline 2 & Isocaryophyllene & 14.483 & $\mathrm{C}_{15} \mathrm{H}_{24}$ & 204 & 11.67 \\
\hline 3 & Ledol & 16.417 & $\mathrm{C}_{15} \mathrm{H}_{26} \mathrm{O}$ & 222 & 10.61 \\
\hline 4 & $\gamma$-Elemene & 15.45 & $\mathrm{C}_{15} \mathrm{H}_{24}$ & 204 & 7.89 \\
\hline 5 & $\beta$-Himachalene & 15.15 & $\mathrm{C}_{15} \mathrm{H}_{24}$ & 204 & 7.38 \\
\hline 6 & $\beta$-Sesquiphellandrene & 15.7 & $\mathrm{C}_{15} \mathrm{H}_{24}$ & 204 & 7.28 \\
\hline 7 & Geraniol ester & 12.567 & $\mathrm{C}_{12} \mathrm{H}_{20} \mathrm{O}$ & 196 & 4.83 \\
\hline 8 & $\alpha$-Muurolol & 17.158 & $\mathrm{C}_{15} \mathrm{H}_{26} \mathrm{O}$ & 222 & 4.66 \\
\hline 9 & $\alpha$-Caryophyllene & 14.917 & $\mathrm{C}_{15} \mathrm{H}_{24}$ & 204 & 4.08 \\
\hline 10 & Chrysanthone & 9.9 & $\mathrm{C}_{10} \mathrm{H}_{16} \mathrm{O}$ & 152 & 3.33 \\
\hline 11 & Camphor & 10.542 & $\mathrm{C}_{10} \mathrm{H}_{16} \mathrm{O}$ & 152 & 2.34 \\
\hline 12 & Borneol & 10.85 & $\mathrm{C}_{10} \mathrm{H}_{18} \mathrm{O}$ & 154 & 2.09 \\
\hline
\end{tabular}

\section{Antibacterial Screening Analysis}

Chloroform extract showed antimicrobial activity against different microorganisms. However, the antimicrobial activity varied according to species of microorganisms.

Table 3: Antimicrobial activity shown by chloroform extract of A. vulgaris in diameter (mm) of inhibition zone

\begin{tabular}{|l|c|c|}
\hline \multirow{2}{*}{ Test Organism $(\mathbf{8 0} \boldsymbol{\mu l})$} & \multicolumn{2}{|c|}{ Zone of inhibition } \\
\cline { 2 - 3 } & Artemisia vulgaris $(\mathbf{1 5} \boldsymbol{\mu l})$ & Control (DMSO) $(\mathbf{1 5} \boldsymbol{\mu l})$ \\
\hline Klebsiella pneumoniae & $8 \mathrm{~mm}$ & No activity \\
\hline Bacillus subtilis KACC 17047 & $6 \mathrm{~mm}$ & No activity \\
\hline Micrococcus luteus KACC 13377 & $15 \mathrm{~mm}$ & No activity \\
\hline $\begin{array}{l}\text { Enterobacter cloaceae subsp. disolvens } \\
\text { KACC 13002 }\end{array}$ & $13 \mathrm{~mm}$ & No activity \\
\hline Pseudomonas sp. & No activity & No activity \\
\hline Staphylococcus aureus KACC 10768 & No activity & No activity \\
\hline
\end{tabular}

\section{Antioxidant Activity}

The antioxidant capacity of plants is associated with the activity of "free radical scavenging enzymes" (superoxide dismutase, catalase, peroxidase, etc.) and the contents of antioxidant substances, mainly phenolic compounds, carotenoids, tocopherol, and ascorbic acid. The antioxidant potential has an inverse relation with $\mathrm{IC}_{50}$ value, which can be calculated from the logarithmic regression of the \% inhibition versus antioxidant activity. Lower the $\mathrm{IC}_{50}$ value higher is the antioxidant activity. All the calculations are based on the standard method [20]. Absorbance was measured at $517 \mathrm{~nm}$.

The absorbance of each solution was measured and recorded as follows

Table 4: Antioxidant activity of Chloroform extract of A. vulgaris sample by DPPH method

\begin{tabular}{|c|c|}
\hline $\begin{array}{c}\text { Concentration } \\
(\mathbf{m g} / \mathbf{m L})\end{array}$ & Percentage Scavenged \\
\hline 0.25 & 15.709 \\
\hline 0.5 & 24.918 \\
\hline 1 & 41.495 \\
\hline 1.5 & 46.912 \\
\hline 2 & 62.838 \\
\hline
\end{tabular}




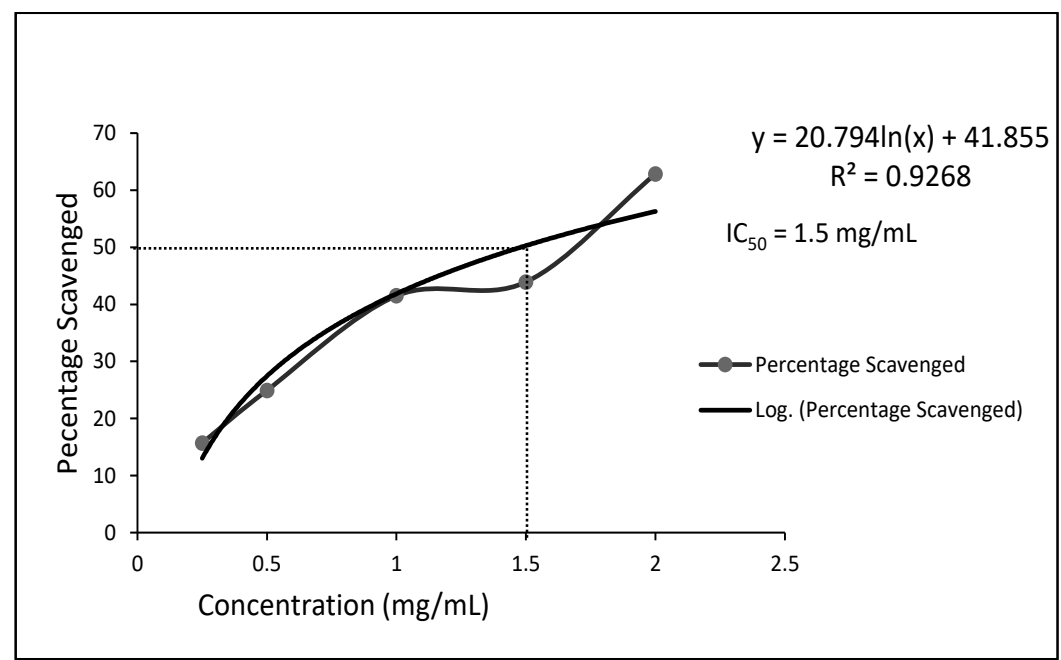

Fig 2: Graphical representation of the DPPH assay of the chloroform extract

According to the Food and Drug Administration (FDA), $\mathrm{IC}_{50}$ represents the concentration of a drug that is required for 50 $\%$ inhibition in vitro. The $\mathrm{IC}_{50}$ value of chloroform extract of $A$. vulgaris was found to be $1.50 \mathrm{mg} / \mathrm{mL}$. This study shows that chloroform extract is more effective in inhibiting a specific biological or biochemical function.

\section{Total Phenolic Content Analysis}

Phenolic compounds are ubiquitous secondary metabolites in plants. They are known to have antioxidant activity, and the activity of these extracts is likely due to these compounds[21]. The total phenolic content was determined as a milligram of gallic acid equivalent using the calibration curve of gallic acid.

The absorbance of each solution as measured and recorded as follows:

Table 5: Absorbance of gallic acid

\begin{tabular}{|l|l|}
\hline Concentration $(\mathrm{mg} / \mathrm{ml})$ & Average Absorbance $(\mathrm{nm})$ \\
\hline 0.01 & 0.03 \\
\hline 0.02 & 0.117 \\
\hline 0.04 & 0.266 \\
\hline 0.06 & 0.429 \\
\hline 0.08 & 0.6 \\
\hline 0.1 & 0.789 \\
\hline
\end{tabular}

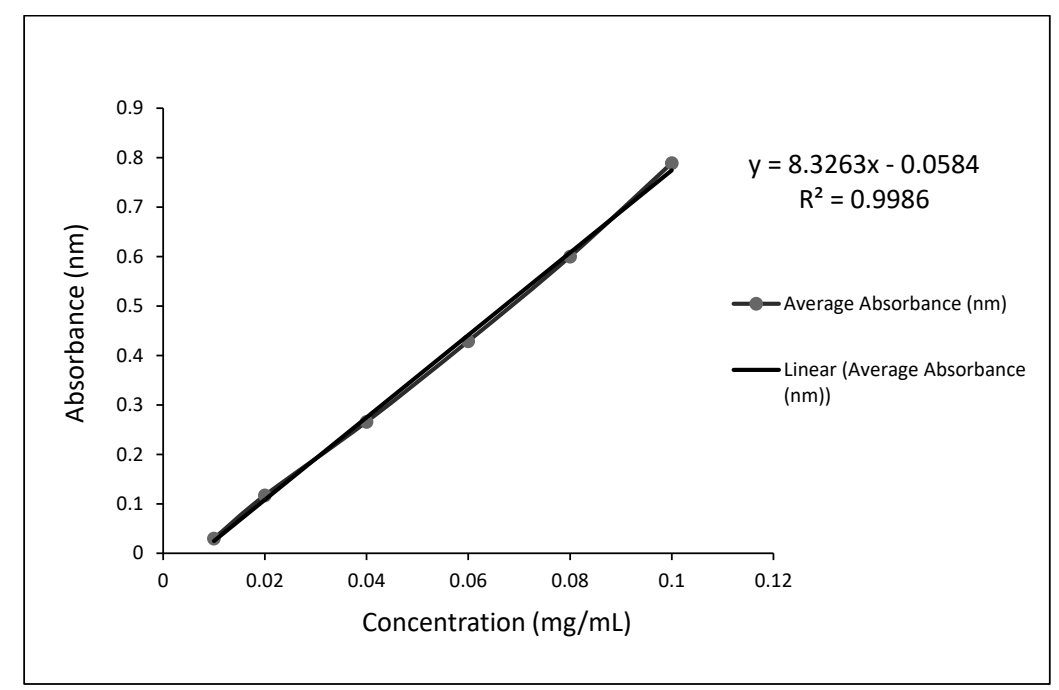

Fig 3: Calibration curve of gallic acid for total phenolic content determination 
The total phenolic content with necessary data is shown in the following table.

Table 6: Total phenolic content in chloroform extract of A. vulgaris

\begin{tabular}{|l|l|c|l|l|}
\hline $\begin{array}{l}\text { Sample Concentration (mg/ } \\
\mathbf{m L})\end{array}$ & $\begin{array}{l}\text { Weight of extract per } \\
\mathbf{m L ~ m}(\mathbf{g})\end{array}$ & Absorbance & $\begin{array}{l}\text { GAC, } \\
\mathbf{( m g / m L )}\end{array}$ & $\begin{array}{l}\text { TPC as GCE } \\
\boldsymbol{C} \times \boldsymbol{v} \\
(\mathbf{m g} / \mathbf{g})\end{array}$ \\
\hline 1 & 0.001 & 0.67 & 0.08775 & 87.75 \\
\hline
\end{tabular}

Based on table 6 and figure 4, the total phenolic content of chloroform extract was tested as gallic acid equivalent by reference to a standard curve $\left(\mathrm{y}=0.0083 \mathrm{x}-0.0584, \mathrm{R}^{2}=0.9986\right)$. The total phenolic content in the chloroform extract of $A$. vulgaris was found to be $87.75 \mathrm{mg}$ gallic acid equivalent $/ \mathrm{g}$ of dry extract, which is shown in table 6 .

\section{Total Flavonoid Content Analysis}

Total flavonoid content was expressed as mg of quercetin equivalents per gram of dried sample [22].

The absorbance of each solution was measured and recorded as follows:

Table 7: Absorbance of quercetin

\begin{tabular}{|c|c|}
\hline Concentration $(\mathbf{m g} / \mathbf{m l})$ & Average Absorbance (nm) \\
\hline 0.005 & 0.06 \\
\hline 0.01 & 0.122 \\
\hline 0.02 & 0.425 \\
\hline 0.04 & 0.96 \\
\hline 0.08 & 1.901 \\
\hline
\end{tabular}

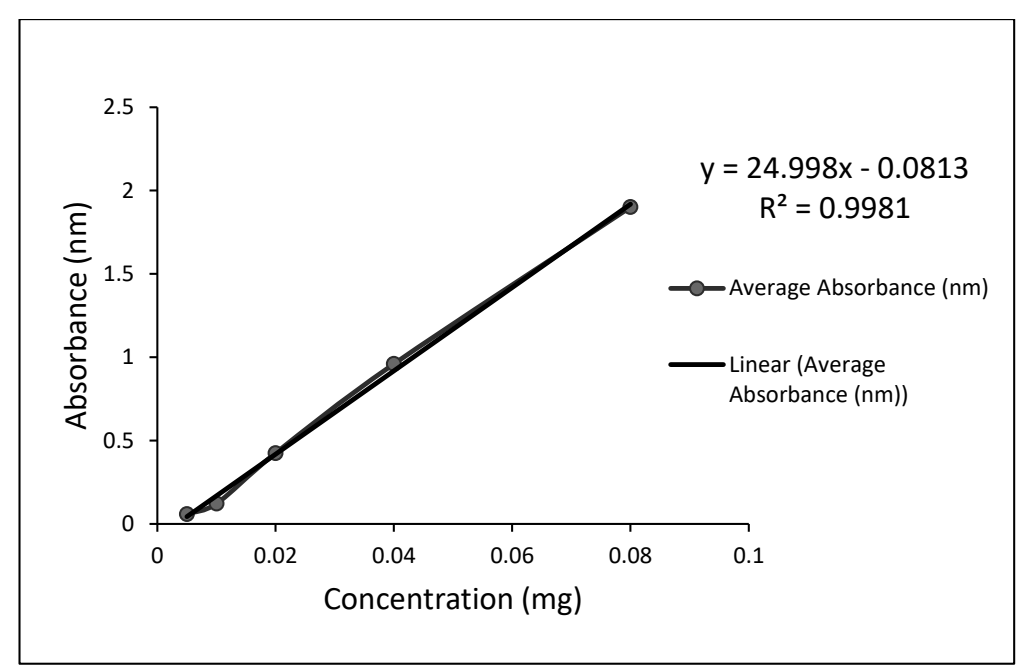

Fig 4: Calibration curve of Quercetin for total flavonoid content determination

The total flavonoid content with necessary data is shown in the following table:

Table 8: Total flavonoid content in chloroform extracts of A. vulgaris

\begin{tabular}{|l|c|c|l|l|}
\hline $\begin{array}{l}\text { Sample } \\
\text { Concentration } \\
(\mathbf{m g} / \mathbf{m L})\end{array}$ & Weight of extract per $\mathbf{m L ~ m}(\mathrm{g})$ & Absorbance & QC, & TFC as \\
& & & C & OE \\
& & & $\frac{\boldsymbol{c} \times \boldsymbol{v}}{\boldsymbol{m}}$ \\
\hline 1 & 0.001 & 1.109 & 0.047252 & 47.252 \\
\hline
\end{tabular}


Based on table 8 and figure 5 , the total flavonoid content of chloroform extract was tested as quercetin equivalent by reference to a standard curve $\left(\mathrm{y}=0.025 \mathrm{x}-0.0813, \mathrm{R}^{2}=0.9981\right)$. The total flavonoid content in the chloroform extract of $A$. vulgaris was found to be $47.25 \mathrm{mg}$ quercetin equivalent /g of dry extract, which is shown in table 8 .

\section{Brine Shrimp Lethality Analysis}

Meyer et al. (1982) used the Brine Shrimp Cytotoxicity Test (BSCT) to determine the lethality of a test sample in a basic zoological organism such as the shrimp (Artemia salina).

The result of the Brine Shrimp Lethality assay are given in the table below:

Table 9: Effect of chloroform extract of A. vulgaris in brine shrimp

\begin{tabular}{|c|c|}
\hline Concentration $(\mathbf{C}) \mathbf{( m g} / \mathbf{m L})$ & Percentage Mortality \\
\hline 0.05 & 14.95 \\
\hline 0.1 & 28.57 \\
\hline 0.2 & 82.98 \\
\hline 0.4 & 93.19 \\
\hline 0.8 & 100 \\
\hline
\end{tabular}

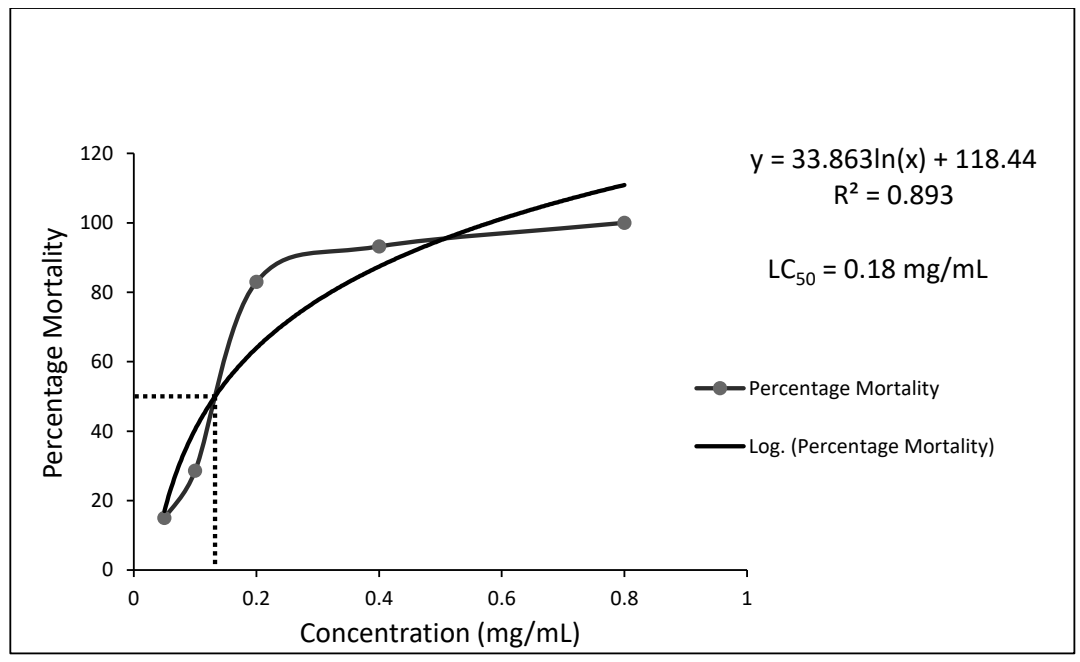

Fig 5: Plot of the concentration of chloroform extract of A. vulgaris versus percent shrimp mortality after 24 hours of exposure

The $\mathrm{LC}_{50}$ value of chloroform extracts of $A$. vulgaris was found to be $0.18 \mathrm{mg} / \mathrm{mL}$, which is considered bioactive in toxicity evaluation.

\section{Conclusions}

The presented results revealed that extract of aerial parts of the $A$. vulgaris plant possesses various bioactive agents. From the preliminary phytochemical screening of the methanolic extract, the various phytoconstituents like flavonoids, phenols, saponins, tannins, glycosides, carbohydrates protein, emolins were identified. The GC-MS analysis of the chloroform extract of $A$. vulgaris showed 12 major compounds; among them Germacrene (33.84\%) was found abundantly. It showed the widest range of zone of inhibition against Micrococcus luteus $(15 \mathrm{~mm})$. The $\mathrm{IC}_{50}$ and $\mathrm{LC}_{50}$ values of chloroform extract were found to be $1.50 \mathrm{mg} /$ $\mathrm{mL}$, and $0.18 \mathrm{mg} / \mathrm{mL}$, respectively, whereas total phenolic and total flavonoid content, were calculated as $87.75 \mathrm{mg}$ gallic acid equivalent/g of dry extract and $47.25 \mathrm{mg}$ quercetin equivalent/g of dry extract respectively.

\section{Acknowledgements}

We value the laboratory facilities provided by the Department of Chemistry, Amrit Science Campus, Lainchaur, Kathmandu, Nepal, and Kathmandu Valley School and College, Chhauni, Kathmandu, Nepal. For the GC-MS analysis, we are grateful to the 
Department of Food Technology and Quality Control, Babarmahal, Kathmandu, Nepal. Thanks also to the Research Institute of Bioscience and Biotechnology (RIBB) in Lalitpur, Nepal, for the bioactivities.

\section{References}

1. F. Anwar, N. Ahmad, K. M. Alkharfy, A. ul H. Gilani. Mugwort (Artemisia vulgaris) oils. Academic Press, 2016, pp. 573-579. (DOI: https://doi.org/10.1016/B978-0-12-416641-7.00065-1).

2. J. N. Barney, A. DiTommaso, The biology of Canadian weeds. 118. Artemisia vulgaris L., Canadian Journal of Plant Science, 2003, 83(1), 205-215. (DOI: 10.4141/P01-098).

3. W. H. El-Tantawy. Biochemical effects, hypolipidemic and anti-inflammatory activities of Artemisia vulgaris extract in hypercholesterolemic rats, Journal of Clinical Biochemistry and Nutrition, 2015, 57(1), 33-38. (DOI: 10.3164/jcbn.14141).

4. P. K. Ashok, U. Kumud. Preliminary phytochemical screening and physico-chemical parameters of aerial parts of Artemisia Vulgaris, International Journal of Research in Ayurveda \& Pharmacy, 2010, 1(1), $206-211$.

5. B. P. Pandey, R. Thapa, A. Upreti. Chemical composition, antioxidant and antibacterial activities of essential oil and methanol extract of Artemisia vulgaris and Gaultheria fragrantissima collected from Nepal, Asian Pacific Journal of Tropical Medicine, 2017, 10(10) (DOI: 10.1016/j.apjtm.2017.09.005).

6. P. Tiwari, B. Kumar, M. Kaur, G. Kaur, H. Kaur. Phytochemical screening and Extraction: A Review, Internationale Pharmaceutica Sciencia, 2011, 1(1), 98-106.

7. S. K. Rathore, S. Bhatt, S. Dhyani, A. Jain. Preliminary Phytochemical Screening of Medicinal Plant Ziziphus Mauritiana Lam. Fruits, International Journal of Current Pharmaceutical Research, 2012, 4(3), 160-162.

8. A. Jain, S. Bhatt, S. Dhyani. Phytochemical Screening of secondary Metabolities of Ziziphus mauritiana Lam. bark, International Journal of Current Pharmaceutical Research, 2012, 4(3), 156-159.

9. F. Medini, H. Fellah, R. Ksouri, C. Abdelly. Total phenolic, flavonoid and tannin contents and antioxidant and antimicrobial activities of organic extracts of shoots of the plant Limonium delicatulum," Journal of Taibah University for Science, 2014, 8(3), 216-224. (DOI: 10.1016/j.jtusci.2014.01.003).

10. F. Opoku, O. Akoto, Antimicrobial and Phytochemical Properties of Alstonia boonei Extracts, Organic Chemistry: Current Research, 2014, 4(1), 10-13. (DOI: 10.4172/2161-0401.1000137).

11. J. Van Cutsem, H. Kurata, H. Matsuoka, Y. Mikami, M. A. Pfaller, G.M. Scalarone, M.G. Rinaldi. Antifungal drug susceptibility testing, Medical Mycology, 1994, 32(S1), 267-276. (DOI: 10.1080/02681219480000891).

12. A. Addo-Mensah, G. Garcia, I. A. Maldonado, E. Anaya, G. Cadena, L. G. Lee. Evaluation of antibacterial activity of Artemisia vulgaris extracts, Research Journal of Medicinal Plant, 2015,9(5), 234-240.(DOI: 10.3923/rjmp.2015.234.240).

13. G. Singh, P. Marimuthu, H. S. Murali, A. S. Bawa. Antioxidative and antibacterial potentials of essential oils and extracts isolated from various spice materials, Journal of Food Safety, 2005, 25(2), 130-145. (DOI: 10.1111/j.17454565.2005.00564.x).

14. A. Singh, A. Ahmad. Antioxidant Activity of Essential Oil Extracted by SC-CO2 from Seeds of Trachyspermum ammi, Medicines, 2017, 4(3), 53. (DOI: 10.3390/medicines4030053).

15. S. Chatterjee, N. Goswami, N. Kothari. Evaluation of antioxidant activity of essential oil from Ajwain (Trachyspermum ammi) seeds, International Journal of Green Pharmacy, 2013, 7 (2), 140-144. (DOI: 10.4103/0973-8258.116396).

16. A. Temraz, W. H. El-Tantawy. Characterization of antioxidant activity of extract from Artemisia vulgaris, Pakistan Journal of Pharmaceutical Sciences, 2008, 21(4), 321-326. 
17. R. Singh, P. K. Verma, G. Singh. Total phenolic, flavonoids and tannin contents in different extracts of Artemisia absinthium, Journal of Intercultural Ethnopharmacology, 2012, 1(2), 101-104. (DOI: 10.5455/jice.20120525014326).

18. B. N. Meyer, N. R. Ferrigni, J. E. Putnam, L. B. Jacobsen, D. E. Nichols, J. L. McLaughlin. Brine shrimp: A convenient general bioassay for active plant constituents, Planta Medica, 1982, 45(1), 31-34. (DOI: 10.1055/s-2007-971236).

19. A. Hamad, M. Arfan, S. A. Khan, N. Fatima, A. M. Abbasi, A. Mannan. Evaluation of antioxidant, antimicrobial and cytotoxic potential in Artemisia vulgaris L. Revista Romana de Medicina de Laborator, 2018, 26(4). (DOI: 10.2478/ rrlm-2018-0020).

20. W. Brand-Williams, M. E. Cuvelier, C. Berset. Use of a free radical method to evaluate antioxidant activity, LWT - Food Science and Technology, 1995, 28(1), 25-30. (DOI: 10.1016/S0023-6438(95)80008-5).

21. S. Oksana, B. Marian, R. Mahendra, S. H. Bo. Plant phenolic compounds for food, pharmaceutical and cosmetics production, Journal of Medicinal Plants Research, 2012, 6(13), 2526-2539. (DOI: 10.5897/jmpr11.1695).

22. K. H. Miean, S. Mohamed. Flavonoid (myricetin, quercetin, kaempferol, luteolin, and apigenin) content of edible tropical plants, Journal of Agricultural and Food Chemistry, 2001, 49(6), 3106-3112. (DOI: 10.1021/jf000892m). 